$$
\begin{gathered}
\text { SF } 253 \\
W_{6}
\end{gathered}
$$





\section{WEIGHTS AND MEASURES}

Regulations Relating to Cream Test Scales and Babcock Milk and Cream Test Bottles

Prescribed by

J. Q. EMERY,

Ex Officio State Superintendent of Weights and Measures

$$
\text { of }
$$

WISCONSIN 
SF 253 WE

i. OF ${ }_{3}$

Nor 18 10:. 


\title{
STATE OF WISCONSIN
}

\author{
OFFICE OF
}

\section{DAIRY AND FOOD COMMISSION AND WETGUTS ANI II EASURES.}

\author{
Madison, January 17, 1914.
}

To Wisconsin Sealers of Weights and Measures:

Subsection 6 of section 1659 of the Wisconsin statutes contains the following provision:

"The superintendent of weights and measurers shall issue from time to time, regulations for the guidance of all sealers, and the said regulations shall govern the procedure to be followed by the aforesaid officers in the discharge of their duties. In said regulations he shall prescribe the amount of tolerance to be allowed."

In obedience to the requirements of this statute, the following regulations are prescribed for the guidance of sealers of weights and measures in the performance of their official duties so far as the same relate to the subject of Babcock milk test bottles, standard Babcock pipettes, Babeock cream test bottles, and cream test and butter fat test seales.

\section{B.ABCock Mil. Test Bottles.}

Babeock milk test bottles complying with the following spe('ifications shall be sealed:

The standard Babcock test bottles for milk shall have a eapacity of two enbic centimeters for each 10 per cent marked on the necks thereof.

The necks of the standard Babcock milk test bottles shall be graduated from zero to 10 per cent and the graduated seale shall be 75 millimeters in length, with an allowable tolerance of 5 millimeters either above or below. The graduated seale shall be divided into per cent and fifth per eent divisions. The fifth per cent graduation marks shall be not less than 3 milli- 

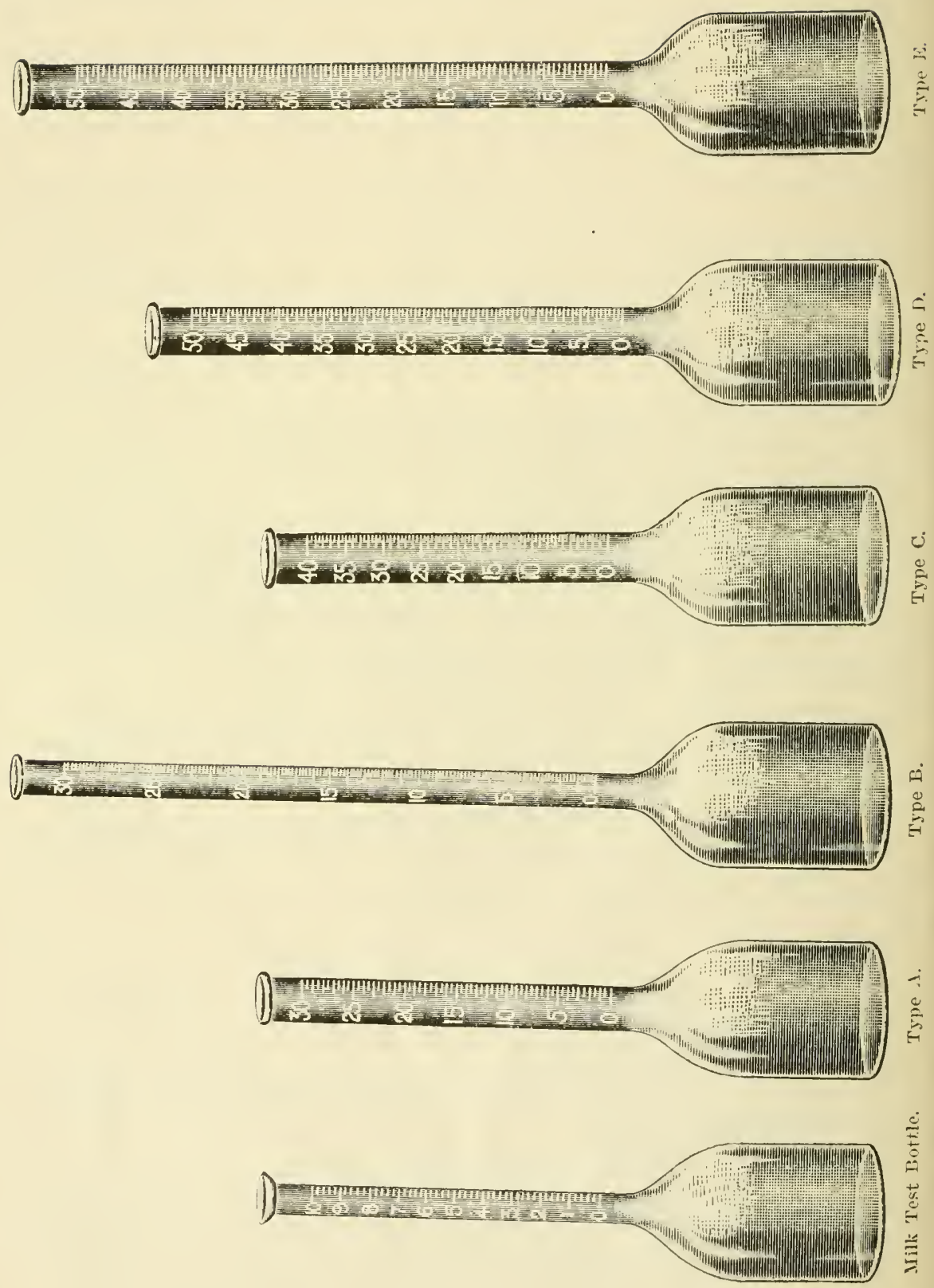
mesters in length and the pere ant gualuation marks shall be not less than 11/2 millimeter's longer than the fifth per cent graduations. Each per cent gratuation shall be numbered and the toleranee for the entire gradnated seale or for any part thereof shall not exereed one-tenth of one pere eent.

The uerks shall be eylindrital for at least 5 millimeters below the lowest and above the highest graduation mark. The top of the nerels shall be flared to an interior diameter of not less than 10 millimeters.

The eapacity of the hull, up to the junction of the neck shall be not less than 40 "nbic centimeters.

The total height of the hottle shall be between 150 and 165 millimeter's.

Each bottle shall bear either a ground surface for idrutifieation number or a permanent identification number.

Sulisection 1 of section 149taa of the Wisconsin statutes provisles as follows:

"In the use of the Bahrock test, the standard milk meastres or pipettes shall have a eapacity of seventeen and six tenths cubir centimeters, and the standard test tubes ol bottles for milk shall have a capacity of two cubie centimeters for each ten per "ent marked on the necks thereof; (') "am shall be tested by weight and the standard nnit for testing shall be eighteen grams, and it is herely made a misclemeanor to nse any other standards of milk or eream measmre where milk or 'ream is purehased by or furnished to ereameries or cheese factories and where the value of said milk or cream is letermined by the per cent of butter fat contained in the same, or wherever the value of milk or cream is determined by the per cent of butter fat contained in the same by the Babcock test."

Referring to the foregoing provisions of law and other laws lorescribing the duties of the state superintendent of weights and neasures, Attorney General Owen has rendered the following official opinion :

"The fact that the statute says that the standard test tubes or bottles shall have a eaparity of two rubie rentimeter's for each 10 per cent marked on the necks thereof implies that the nerks should have marked thereon the 10 per cent mark. I believe that a so-ealled nilk test bottle having only \& per ent mark on the neek is, therefore, not in eompliance with the provision of this law and you are, therefore, instructed that you would not be warranted in approving the same.'" 


\section{Standard Babcock Pipettes.}

The stanclard pipettes shall have a capacity of 17.6 cubic centimeters.

The total length of pipette shall be not more than 330 millimeters (131/4 inches).

The outside diameter of suction tube thall be 6 to 8 millimeters. The length of the suction tube shall be $130 \mathrm{mill}$ meters. The outside diameter of the delivery tube shall be 4.5 to 5.5 millimeters. The length of the delivery tube shall be 100 to 120 millimeters. The distance of the gradnation mark above the bull, shall be 30 to 60 millimeters. The nozzle shall be straight. When filled with water at $20^{\circ} \mathrm{C}$. delivery shall be in 5 to 8 seconds. The tolerance shall not exceed .05 cubie centimeter.

A pipette having a capacity of 18 enbic centimeters or having any other capacity than that above specified, nanely 17.6 cubic centimeters which is the only pipette that eomplies with the terms. of the law, must not be sealed.

Note. Section 1494aa of the Wisconsin statutes contains the following provision :

"Cream shall be tested by weight and the standard unit for testing shall be eighteen grams, and it is hereby made a misdemeanor to use any othel standards of * * * cream measure where * * * cream is purchased by or furnished to creameries or cheese factories and where the value of said *** cream is determined by the per cent of butter fat contained in the same, or wherever the value of * * * * *am is determined by the percent of butter fat contained in the same by the Babcock test."

\section{B.ABCOCK CREAM Test BotThes.}

Babcock cream test bottles of the following types and complying with the following specifications are to be sealed:

Type A. Thirty per cent, 18 gram, 6 inch, 1/2 per cent gradmations. Each 5 per cent on the neck of the bottle shall represent a volnme of 1 cubie centimeter.

The neck of the bottle shall be graduated from zero to 30 per cent and the gradnated scale shall be 75 millimeters: in length, with an allowable tolerance of 8 millimeters above or below. The gradnated scale shall be divided into 5 
per cent, 1 per cent and 1/2 per cent divisions, 'The $1 / 2$ per eent graluation marks shall be not less than 3 millimeters in length. The 1 per eent graduation marks shall be not less than $11 \%$ millimeters longer than the $1 / 2$ per cent graduations. The 5 per cent graluation marks shall be not less than $1 \frac{1}{2}$ millimeters longer than the 1 per cent graduation marks. Wach 5 per cent graduation shall be numbered. The allowable tolerance for calibration shall not excecd $1 / 2$ per eent for the entire graduated scale or for any part thereof.

The capacity of the bulb up to the junction of the neek shall be not less than 40 enbic eentimeters.

Fach bottle shall bear either a ground glass surface for identifieation number or a permanent identifieation number.

The neck shall be eylindrical for at least 5 millimeter's below the lowest and above the highest graduation mark. The top of the neek shall be flared to an interior diameter of not less than 10 millimeters.

The standard mit for-testing shall be 18 grams.

The total height of the bottle shall be between 150 and 165 millimeters $(5 \% / \mathrm{s}$ and $61 / 2$ inches).

Type B. Thirty per eent, 18 gram, 9 inch, .2 per cent graduations.

The neck of the bottle shall be graduated from zero to $30 \mathrm{per}$ cent and the graduated scale shall be 125 millimeters in length, with an allowable toleranee of 10 millimeters either above or below. The graduated seale shall be divided into 5 per cent, 1 per cent and .2 per cent divisions. The .2 per eent gradnation marks shall be not less than 3 millimeters in length. The 1 per cent and 5 per eent graduation marks shall be not less than 1.5 millimeters longer than the .2 per cent graduations. The allowalne tolerance for calibration slall not exceed .2 per cent for the entive graduated scale or for any part thereof.

The total height of the bottle shall be between 210 and 225 millimeters ( $81 / 4$ and $87 / 8$ inches).

11 other specifications are to be the same as for Type $\Lambda$.

Type C. Forty per eent, 18 gram, 6 inch, $1 / 2$ per cent graluations.

The neck of the bottle shall be gradnated from zero to 40 per eent and the graduated scale shall be 75 millimetcrs in length, with an allowahle tolerance of $S$ millimeters either above or below. 
All other specifications are to be the same as for Type $A$.

Type D. Fifty per cent, 18 gram, 7 inch, $1 / 2$ per cent gradllations.

The neck of the bottle shall be graduated from zero to 50 per cent and the graduated scale shall he 105 millimeters in length, with an allowable tolerante of 10 millimeters either above or below.

The total height of the hottle shall be between 180 and 195 millimeters ( $71 / 5$ and $7 \because 4$ inches).

All other speeifications are to be the same as for Type $\mathrm{A}$.

Type E. Fifty per cent, 18 gram, 9 inch, 1/2 per cent gradnations.

The neck of the bottle shall he graduated from zero to 50 per cent and the grathated scale shall be 125 millimeters in length, with an allowable tolerane of 10 millimeters either above or below.

The total height of the bottle shall be between 210 and 225 millimeters ( $81 / 4$ and $8 \% / \mathrm{s}$ inches).

All other speedifeations are to be the same as for Type $\lambda$.

Referring to the provisions of section 14!) taa of the Wiseonsin statutes hereinbefore quoted, Attorney General Owen has rendered the following official opinion relative to 9 gram cream test hottles:

"Inder this statute it is provided that "eream shall be tested by weight and the stantard mit for testing shall be 18-grams and it is hereby made a mistemeanor to use any other standards of milk or 'ream measure,' etc. As 18 grams are expressly mentioned as the standard mit nsed in testing. and as no mention is made of a 9-gram standard unit, I am of the opinion that only the 18-gram cream test hottles ran be nsed and the 9-gram cream test bottles should be rondemned."

\section{Crean Thes and Buteter F.at Test sches.}

The swale shall be provided with a graduated plate of at least ten divisions over which the pointer plays.

The pointer shall reach to the gradnated divisions and shall terminate in a fine point to enable the readings to be made clearly and distinctly.

The clear interval between the divisions on the graduated face shall not be less than .05 inch. 
Beam seales and trip balances provided with knife edges and bearings shall be provided with leveling serews and an attaehed level.

The seale shall be so eonstructed and adjusted that when the pans are released or disturbed the pointer will return to rest at the zero mark.

The addition of 32.4 milligrams or one half grain to the scale when loaded to capacity shall eause a movement of the pointer at least equal to one division on the graduated face.

The tolerance either in exeess or defieiency when the seale is fully loaded shall be one grain.

II eights. A toleranee of 20 milligrams is allowable in 18 gram weights and 10 milligrams in 9 gram weights. The manufacturers' tolerance shall be one half this amount.

rote. To avoid liability of penalty for violation of the weights and measures law by the use of any unsealed weight, seale, measure or measuring appliance of any deseription, including new appliances, or any sueh appliance that has not been sealed within one year, owners of the same shonld give notice in writing to the state superintendent of weights and measures, Madison, Wis., or to the city sealer if in a city having a eity sealer of weights and measures, of the fact that they have sueh weight or measure or weighing or measuring deviee, giving a deseription of the same and its location. See sulsection 3, section 4432 Wisconsin statutes.

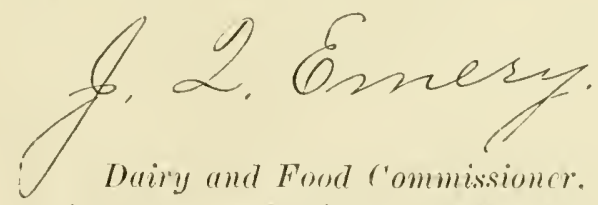

lix officio state supcintendent of Heights and Mcasures. 
OfFice OF

Dairy and Foon Commission and Weights and Measures.

Madison, Wis., March 4, 1914.

To Cheese Factory and Creamery Managers, Cheese Makers and Butter Makers:,

Paragraph 3 of section 1659 of the Wiseonsin statutes relating to weights and measures places a general supervision of all weights and measures and weighing or measuring deviees of the state in the hands of the state superintendent of weights and measures. It further provides that he or his inspectors by his direction shall, upon the written, request of any citizen, firm or eorporation, or educational institution of the state, test or calibrate weights, measures, weighing or measuring devices, and instruments or apparatus used as standards in this state.

Under the provisions of this aet, owners of ereameries and eheese factories may send to the office of weights and measures at Madison, Wis. any Babcock milk, cream, or butter test bottles, any milk pipettes, and any scales or weights nsed in the weighing of cream samples, and the same will be tested. No fees are charged for testing. Many managers are now ordering their new supplies sent direct to the office of weights and measures for testing and sealing, thus insuring aeeuraey before being put to use, with little or no inconvenience. In sending in old glassware, it is best to send only part of the supply on hand at one time, as sometimes several weeks may elapse before the glassware can be returned.

In sending apparatus for testing and sealing the following rules should be complied with:

1. Aidress all packages to J. Q. Emery, Office of Weights and Measures, State Capitol, Madison, Wis.

2. The name and address of eonsignor should be plaeed on the outside of the package.

3. Transportation charges on packages shonld be prepaict. 
4. If consignor desires package to he returned by pareel post, postage should be enelosed in letter to pay for return of same.

5. Bottles to be tested must be thoronghly eleaned before sending, so that all sediment or deposit on the inside of the lottles is removed. No tests will be made of glassware that is not thoroughly eleaned when submitted.

6. Extreme eare should be exereised in packing such glassware or seales for shipment, as this department will not be responsible for breakage.

\section{J. Q. EMERY,}

Dairy and Food Commissioner, Ex officio State Superintendent of Weights and Veasures. 
(REAII TEST SOALES ANI) BABCOCK TEST' BOTTLES.

By F. P. Dowxixg, Chief Inspector of Weights and Measures.

\section{CREAM TEST SCALES.}

Many articles have been published npon the testing of milk and cream hy what is commonly known as the Babcock method. In obtaining the percent of milk fat by this means the operator starts with a known volume or weight of the sample, places it in a graduated milk or cream bottle, treats it with sulphuric acid and then after centrifuging or whinling the bottle a definite period, reads the percent of fat directly from the bottle. In making the above test, skill and experience are required to secure accurate results. But no matter how carefiul the operator may be, it will he imposilbe for him to get correct results if he is not prorided with accurate glassware and sensitive and aecurate scales.

In the past, the creameries of the state have been obliged to depend largely upon the advice of salesmen when ordering supplies and apparatus with which to work. This has resulted in the purchase of certain types of scales entirely unfit for the purpose for which they were purchased, and the use of such scales has heen the canse of great errors and heavy losses.

There was a time when an 18 ce. eream pipette was considered suffieiently aecurate to use in making cream detcrminations. But when it hecame known that such a pipette would deliver 17.9 grams of a $10 \%$ eream and only 15.8 grams of a $50 \%$ cream, the cream pipette was replaced by various types of cream test scales. The wide range in the specific gravity of eream showed the unreliability of the use of a pipette. Every intelligent creameryman is now aware of this. But it is not so generally known that errors approximately as great as those obtained through the nse of the cream pipette may be obtained by the use of inaccurate and insensitive cream test scales.

The better class of books on the testing of cream give minute explanations to the operator concerning various ways in which 
mistakes or errors in the reading of the fat content of the cream are produced, the proper temperature at which to take readings, the proper method of reading the menisens, the strength of the arid to be nsed, and the nmmber of revolutions made by the centrifuge. These and other essential details are describerl, but little or nothing has ever been published with regard to the errors that arise through the use of inaceurate cream test scales.

Investigation shows that many of the mistakes now made in the ereameries in this state in the determining of the fat content of cream are due, not simply to the canses enumerated in the paragraph above, but to the use of scales of improper construction. Frequently creamerymen find themselves unable to obtain duplicate tests in the determination of the percent of cream. Frequently farmers send their cream to the state dairy and food commission, to the university, or to the county training schools for analysis and the results obtained differ from the readings given at the factory. In a number of instances, this difference has been found to be due to the use of eream seales that are not sufficiently sensitive.

For the purpose of determining what types of cream scales were the most aecurate and the best adapted to weighing a nine or eighteen gram sample of eream, state inspectors of weights and measures were sent to various creamcries of the state to inspect the seales in use and to check up the weights obtained upon such scales by the creamerymen. The buttermaker at the ereamery was asked to weigh a given number of samples of cream on his scale, following the methods pursned by him in his daily work at the factory. In practically every instance, greater than usual care was taken in making the weighings. The bottles containing the samples of cream were then securely corked and brought to the office of the state department of weights and measures at Madison, where they were reweighed on a delieate bieker offee balanes sensitive to .1 milligram. The results obtained were indeed surpiring and are given in 'Talsle $\mathrm{I}$. 


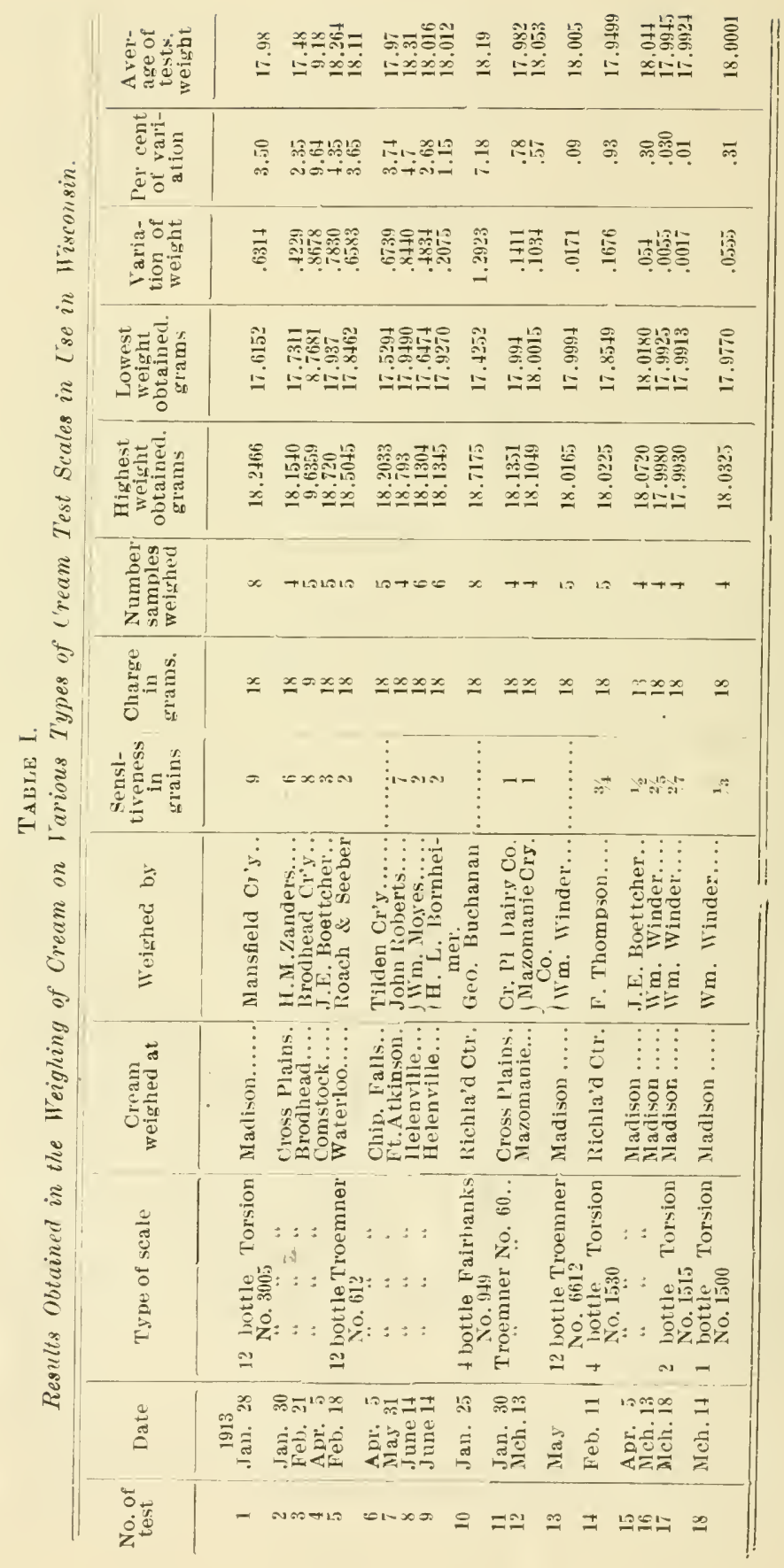


$A$ careful stuty of this table reveals the fact that the more sensitive the seale the smaller the error resulting in woighing the cream. For instance, in test No. 1 the error of variation in duplicate tests amounted to $3.5 \%$. In test No. 18 the variation was only $.31 \%$. The first scale lad a sensitiveness of nine grains, whereas the latter was sensitive to one-third grain. In test No. 3 male at brodhead 9 gram samples were weighed and the variation was $9.6 \pm \%$. It is clear from this that the smaller the charge the greater will be the perrentage of error accruing through the use of a sluggish scale. If a nine gram sample had been taken in test No. 1 instead of an 18 gram, the variation in duplieate tests would undoubtedly have been about $7 \%$.

'Tests Nos. 8 and 9 made at Helenville by Mes-rs. Moyes and H. L. Bormheimer show the personal factor in the use of a seale. In this instanee Mr. Moyes, the buttermaker, weighed six samples of cream upon the seale, following which $\mathrm{Ml}_{\mathrm{r}}$. Bornheimer weighed the remaining six samples. On checking up the weights obtained by these two meli, it was found that the variation in weighings in the ease of Mr. Moyes amounted to $2.68 \%$, while in the ease of Mr. Bornheimer the variation was but $1.15 \%$. The types of seales used in making the tests given in Table I were the twelve bottle torsion balance No. 3005, the twelve Jottle Troemmer balance No. 612, the four bottle Fairbanks Troemner balanee No. 6612 with hanging pans, the four bottle torsion balanea No. 1530, the two bottle torsion balance No. 1515 and the one bottle torsion balance No. 1500. (See Illustration).

The figures show that accurate results are unobtainable through the use of the twelve bottle torsion balance 3005 , the twelve bottle Troemner balance No. 612, and the four bottle Fairbanks balance No. 949 when the same are sluggish and insensitive in their aetion.

Seale mannfacturers eoncede that it is almost an impossibility to make a twelve bottle seale with overhead pans which will remain sensitive to $1 / 2$ grain and not show a greater error at full load than one grain.

The figures in Table I likewise show that the speeifieations for eream seales must differ radieally from the speeifications applied to the ordinary commereial weighing applianees used in groeery stores and meat markets. It is not neeessary for a grocer's balanee to be sensitive to one or two grains. He weighs his groceries in large quantities. An error of one grain in the 


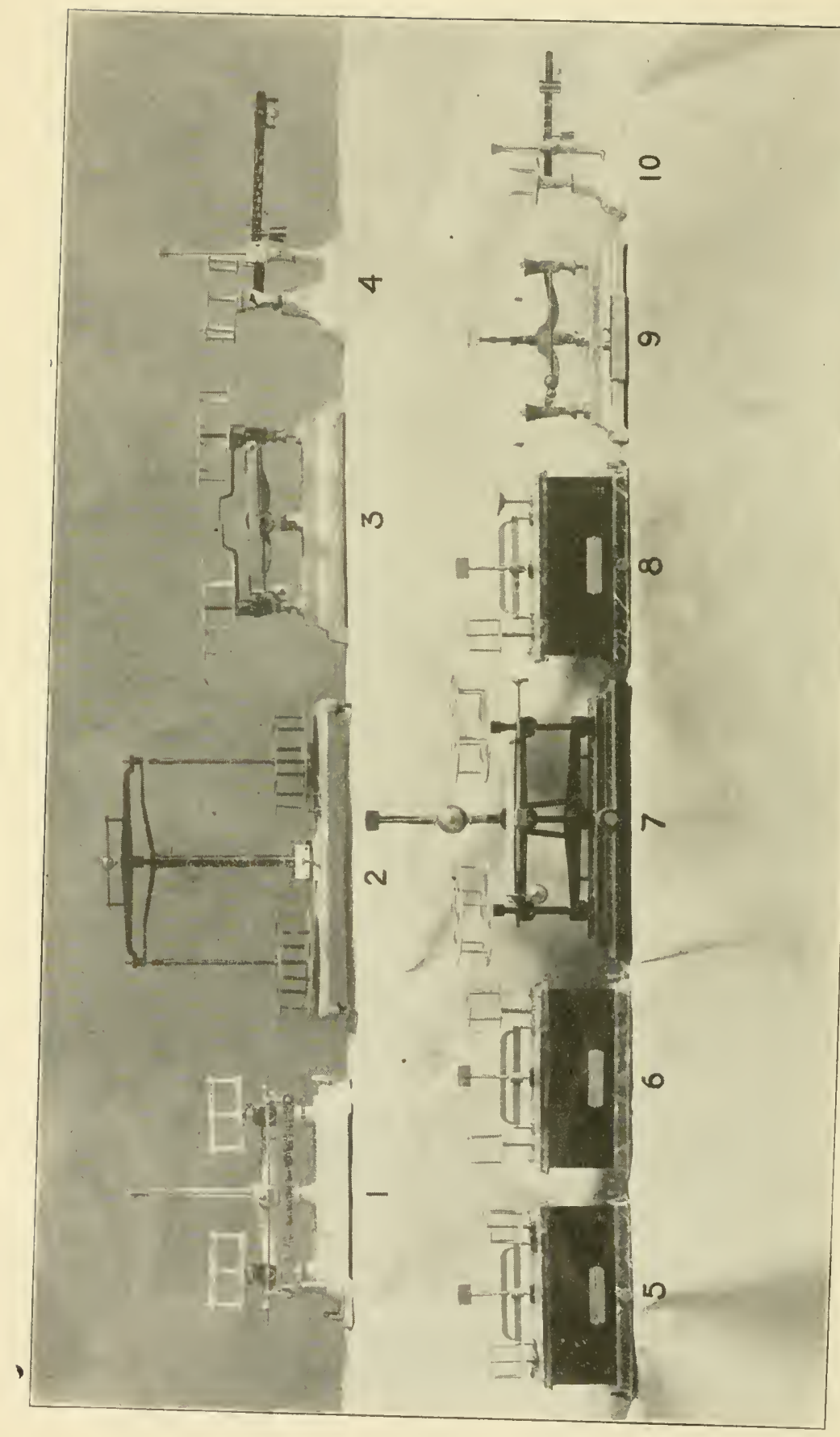

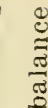

芩

임

ป

-

¿

क $\cong$

6 응

10.

is

는

동

$\stackrel{\Xi}{3}$

满

ะ อ

范

$\stackrel{0}{2}$

एँ

$\Xi \pm$

릴

$\circ$

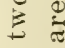

อี ลิ

รี

䓛

कर

20

हू

क

है

ฐ

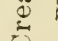

ช

$\stackrel{0}{2}$ 
weighing of a pound of tea would be an error of ouly $1 / 7000$ of the load while an error of one grain in the wrighing of a nine gram sample of eream would he an error of $1 / 139$ of the sample, the proportionate error heing fifty times as great in the weight of the cream as it is in the weight of the tea.

To slow the losses resultiug through the use of inaceurate seales, a few cases are cited, taking the figures from Table I.

In the case of 11 . M. Kanders of Cross Plains, the average weight of the tests was 17.48 grams, the error heing mimus .52 grams or 2.89\%. The sror on 10,000 1bs. of hutter fat would amount to 289 llos. It 25 c.ts. a pound for butter fat the loss to the patrous would be $\$ 72.25$.

In the ease of test No. 7, John Roberts of Fort Atkinson, the average weight of the tests was 18.31 grams, the exeess weight being .31 grams $0 \mathrm{r}^{*} 1.72 \%$. The error on 10,000 pounds would he 172 pounds. At 25 cts. a pound the loss to the creamery would be $\$ 43$.

Tn test No. 3 at the Brodhead Creamery the highest reading of the nine gram sample ohtained showed an error of 6359 grams or $7.06 \%$. The loss to the creamery on 100 pounds of butter fat at 25 ets. a pounc? in this case would amount to $\$ 1.76$. The lowest individual reading ohtained at the Brodhead Creamery was .2319 grams short of 9 grams or $2.57 \%$. The gain to the ereamely on 100 pounds of hutter fat at 25 ets. a pound in this ease would amount to 2.57 pounds valued at 64 cts. By using seales sensitive to $1 / 2$ arain or less, the errors are very slight, almost negligible.

The results obtained in l'able. T applied to scales in actual nsse, some of whieh were a number of years old.

To be absolutely sure that the unfitness of the types of scales mentioned in Table $I$ is due largely to the inherent construction of the seale and not to the operator of the scale, nor to imperfeetions brought about through use, manufacturers of cream test scales rere requested hy the state department of weights and measures to submit different types of new scales which they manufactured. The manufaeturers were perfeetly willing and glad to eoöperate with the department in this matter and in eaeh ease a loan of the different types of scales manufactured was made to the department. 


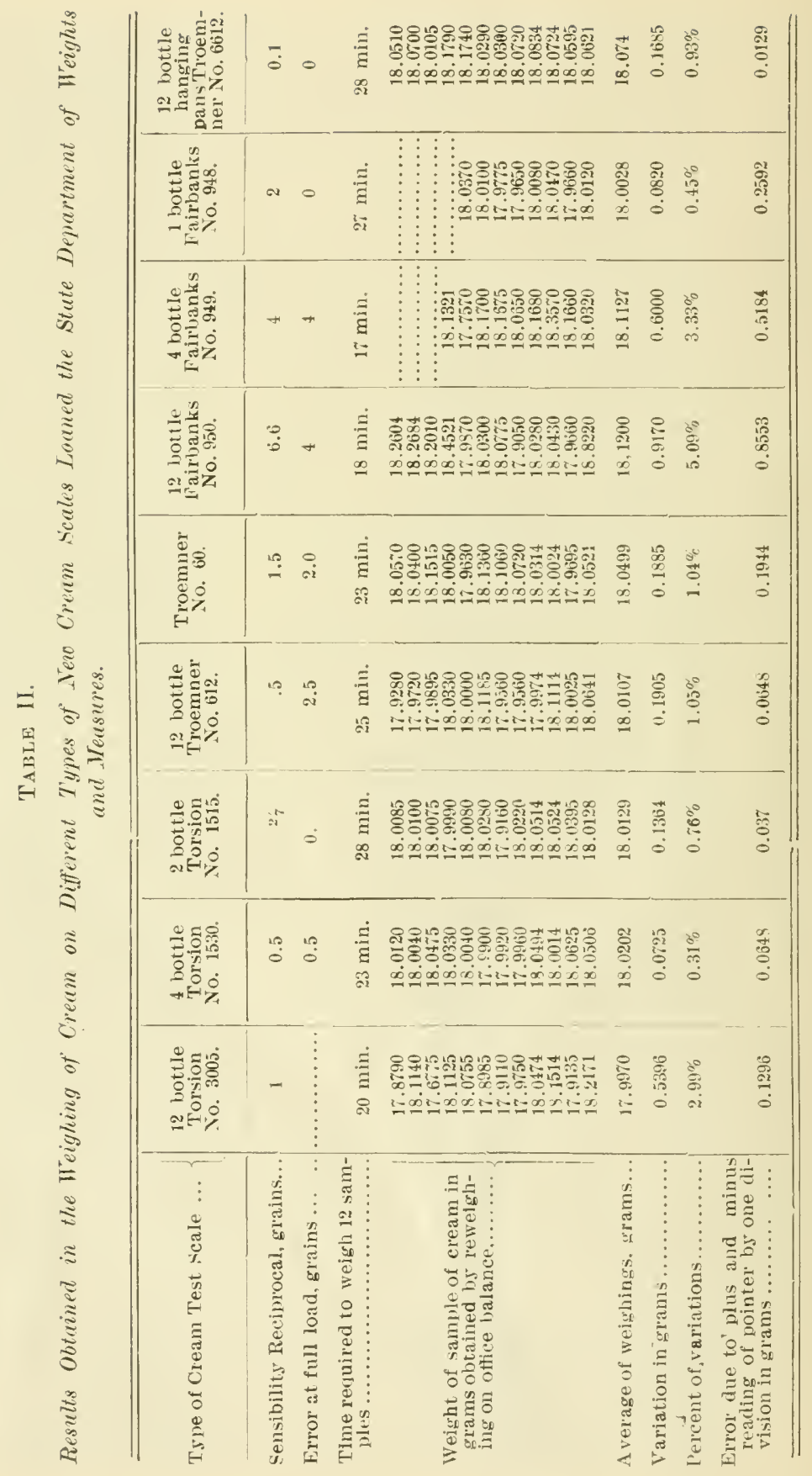


Table II gives the results of the weighings made upon these new seales. Twelve 18 gram samples of eream were very carefully weighed upon each type of seale, extreme eare being taken in placing the cream in the Babeock bottles not to add an exeess. If a few drops of cream in exeess were aceidentally poured into the bottle, the same were removed so as to bring the scale baek as near as possible to a perfeet balance. The samples were then reweighed upon the Becker office balanee and the variations in weight recorded. The results obtained again show that the more sensitive the seale, the more aceurate the weighings reeorded and the less the variation of duplieate samples. By studying the variation of the duplicate weights in grams, it will be observed that the greatest variations were obtained upon the twelve bottle Fairbanks eream test scale No. 950, the four bottle Fairbanks cream test scale No. 949 and the twelve bottle torsion balance No. 3005. In these experiments the twelve bottle Troemner balanee with hanging pans, No. 6612, is the only type of twelve bottle eream test seale that gave reasonably aecurate results.

The errors resulting through the use of the twelve bottle Troemuer No. 612 and the Troemner seale No. 60 are almost identieal. It will be noted that the twelve bottle Troemner No. 612 submitted to the state department of weights and measures is an exeeptionally sensitive scale for one of this type.

It seems neeessary at this point to explain the meaning of the term sensitiveness. More teehnically speaking, this term should be called the "sensibility reciprocal". It is defined as the weight in grains required to move the pointer over one scale division. Where the seale was not provided with an indieator as was the ease in the twelve bottle Troemner No. 612 the sensibility reciproeal was considered as the weight which when placed on the pan would move the pointer a distanee equal to the thickness of the pointer, or about three millimeters.

Comparing the results obtained on the twelve bottle Troemner No. 612 in Table II with the results obtained in Table I, it will be observed that the sensitiveness of this seale decreases rapidly with use. This is no doubt due to the fact that there are a large number of frietion points. Exposure to moisture rusts the connecting rods beneath the hase of the seale, produeing shggishness in its aetion.

Attention is ealled to the figures in the last row of Table II in which the error due to a plus or minus reading of the pointer 
one scale division is recorded. These figures are ohtained by multiplying the sensitiveness of the scale in milligrams by tro. In the ordinary operation of cream test scales the operator nndoubtedly frequently overloads or moderloads his scale an amount which would cause the pointer to deviate one division to the right or left. In doing this the error for the different types of scales depends strictly upon the sensitiveness of the seale. By comparing the figmres in this row with the figmes shown in the row indicating the actual variation in grams of the duplicate weighings an idea is given of what proportion of the variation is due to the use of a sluggish scale and what proportion is due to the personal element.

There seems to be a prevailing opinion among ereamerymen of the state that the use of a twelve hottle cream test scale results in the saving of much time. To determine just what this saving woukl amount to a record was kept of the number of minutes rerpuired to make twelve weighings and the figures are recorder in the third line of Table II. The results show that the more sluggish and insensitive the seale the less time is required in making trelve weighings. It will be observed that twenty mimntes were required to make twelve weighings on the twelve bottle Torsion balance No. 3005 and but twenty-three minutes in weighing twelve bottles upon the four bottle torsion balance No. 1530. This time included the balaneing of the four bottle balance three times. While the ability to make rapid weighings on a cream test scale is important, nevertheless accuracy should nerer be sacrificed for speed. While it required three minutes more to make twelve weighings on the four bottle torsion balance than it did upon the twelve bottle torsion balance, the percent of variation in the twelve bottle balance was about ten times greater than that obtained in the use of the four bottle balance.

A cream test scale should fulfill the following requirements :It should be sensitive to one drop of cream, which is approximately thirty-two milligrams or one half grain. The maximum error permissible at full load or less should not be in excess of 64.8 milligrams or one grain. If of the beam or lever type, it should he provided with leveling serews and a level so that the errors due to weighing on a scale out of level ean be avoided. If provided with a tare weight this weight should not be so heary that it is diffieult to bring the scale into balance through 
a very slight morement of the tare weight. A tare weight which moves upon a threaded rod is much easier to manipulate than one that slides along a smooth rod. The weight of samples of cream should not vary on different parts of the pan, which is found to be the case with some of the twelve bottle cream test seales. 'The scale should be provided with a pointer whieh plays over a graduated indicator. It is extremely diffienlt to use a seale with two bhut pointers, such as are found in the twelve bottle Troemner cream test scale, and obtain accurate results. The scale should respond quickly so that time will not he lost in the operation of wrighing.

In order that acenrate testing be done in creameries, the operator must be provided with proper utensils. It is of the highest importance that the scale be accurate and sensitive. It must be remembered, howerer, that even if a new scale does wrigh accurately it will soon beeome slnggish and inacenrate if it is not properly cared for. Comparatively few ereameries give proper care and attention to the cream test scales in use. They are left exposed in a damp, room and become rusted. Dirt and dust accumulate on the bearings. The weighings are frequently made upon surfaces that are not level. A seale, to weigh accurately, must be kept clean and free from the moisture and dirt of the factory. The life of the scale could be greatly prolonged if the operator went to the slight additional expense of purchasing a glass frame or corer in which to keep his seale - when not in nse. A level shelf should be provided for the seale. 'This shelf should he free from all jars and vibrations due to the movement of the machinery in the creamery. One of the state inspectors reports that in visiting a creamery he found that the operator had placed his eream test scale upon the top of the centrifuge while the same was in motion and was making his weighings nuler these totally unfit ronditions. It it any wouder that inacenrate results are obtained nnder such adverse conditions?

\section{B.ABCOCK T'EST BOTTLES.}

The Babcock method of testing milk and ream is rolumetrie, the unit of graduation heing the true cubic centinster or the volume oceupied by one gran of distilled water at 40 C. In the 18 gram hottle each cubir rentineter represents is on the graduated neck of the bottle. 
That there is great need in Wisconsin for establishing specifications relating both to the form and aceuracy of Babcock glassware is revealed by investigations carried on by the state department of weights and measures. Thousands of Babcock bottles have Anring the past year been tested by this department and large numbers have been found inacenrately gaduated, in a few eases the inacemacies amounting to as much as $4 \%$ or $5 \%$ on a $50 \%$ eream test bottle. A bewildering variety of types of Babcoek bottles is now listed in the catalogues of glass ware mannfacturers. A few of this multitudinous variety of types of bottles are so constructed that they can he readily used in obtaining accurate results in the reading of the fat content of milk or cream. The remaining types are worse than worthless as they are mislearling to the dairymen. The nse of the wide neek bottle is especially objectionable. The use of bottles in which the graduations are placed very close together is likewise objectionable, it being impossible to obtain accurate results when either of the above oljectionable types of bottles is used.

In the rearling of cream the fat content should be read to at least within $.5 \%$. This being the case, crean test bottlus graduated in $1 \%$ divisions should not be sealed. Dividers should be used in making the reading.

Specifications prescribing the minimum and maximum length of the graduated neck of both milk and cream bottles are necessary for two reasons. First, it is to the manufacturer's advantage to use tubing having a wide variation in diameter. If no limit is placed on the diameter of the tubing used, the manufacturer to avoid waste uses up all available tubing, thus producing a varying percentage of bottles with extremely wide necks and graduations erowded closely together. While snch bottles may be accurately calihrated they are difficult to read. Second, the graduations on the 6 incli weam test bottles, which originally did not exceed $30 \%$ or $40 \%$. have been increased to $50 \%$ 01 $55 \%$. The graduations are thus erowded together so closely that accurate reading is practically impossible. It is not in the interest of accuracy to have the distance between graduations appreciably less than one millimeter.

In determining types of bottles which will be approved for sealing by sealers of weights and measures, the work was done on the theory that specifications should be of such a nature as 


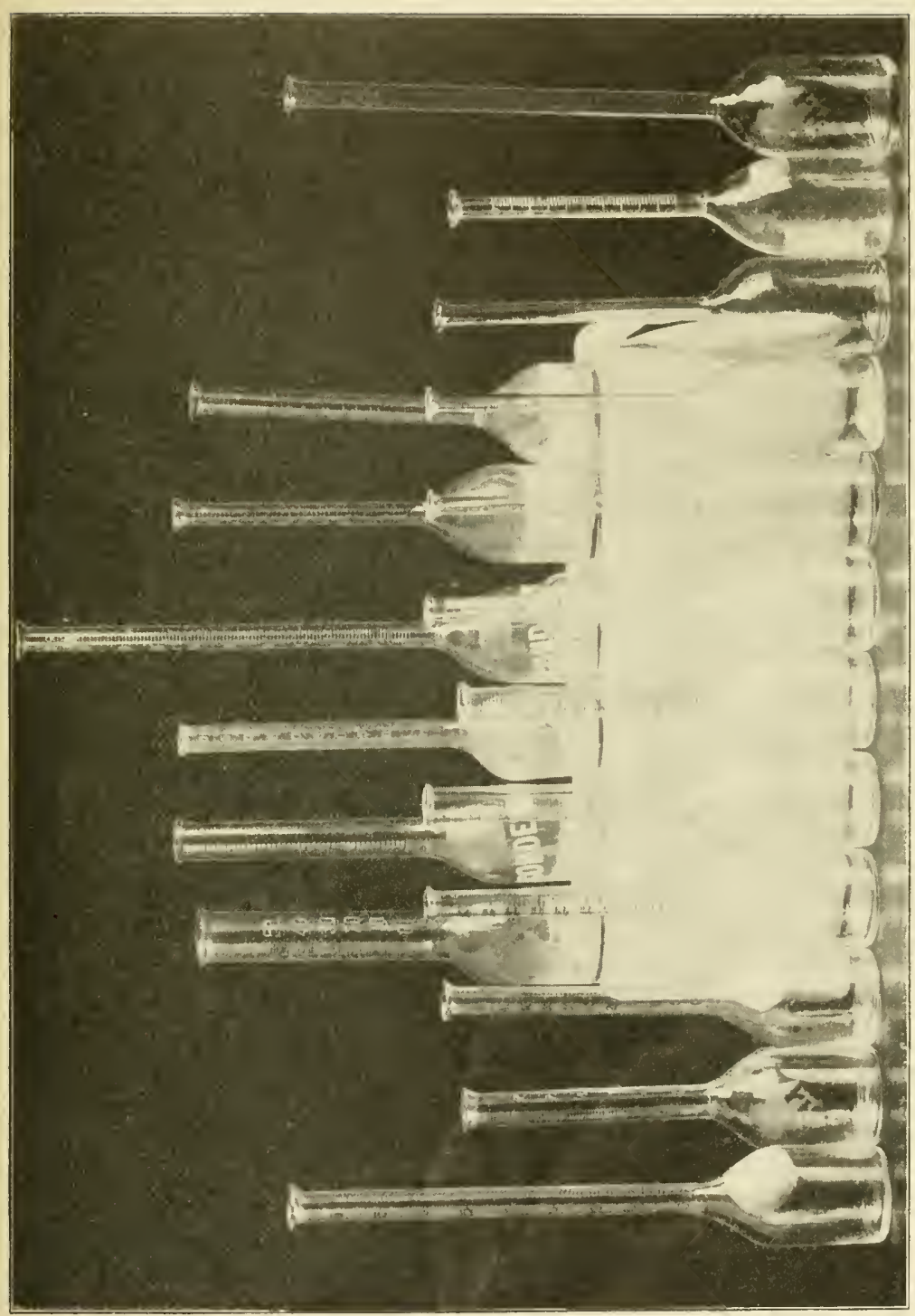

$\stackrel{ \pm}{\circ}$

学

के

$\stackrel{\square}{\square}$

ఖ

$\Xi$

(ㄴ)

0

$\equiv$

$\stackrel{7}{=}$

¿ 0

는

$\geqslant$

$\approx$

$\therefore$

ㄷำ

on

$=$

$= \pm$

$\cong 0$

Q

$=4$

$\circ$

$\rightarrow \frac{1}{0}$

卷导

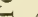

(⿻)

एँ

80

元

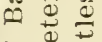

0 政

v.

के

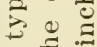

on

$\stackrel{5}{\overline{0}} \equiv$

$\div$.

$\stackrel{0}{\Xi} \cong$

$\exists \Xi$

$\approx 0$

$\stackrel{\Xi}{\varpi} \cong$

$\leftarrow$ \%

-

(c)

$\varangle$ 
to lead to the securing of accurate results. The work was not done on the theory that specifications for Babcock hottles should be snch as to grant the mannfactnrer a wide latitude in the selection of his tubing. Neither are the specifications prepared on the theory that cream bottles should be so elosely graduated as to permit the reading of cream with a high fat content when eentrifuges of a narrow diameter are nsed. Aecuraey must not be sacrifieed for miere convenience; neither should the matter of a few dollar's extra expense to the ereamerymen be the essential consideration. The purchase of defective glassware at any price is a short sighted policy. Sinch glass ware must utterly fail to accomplish the legitimate purpose of its use.

Specifications are prescribed for five types of cream test bottles. When cream does not run above $30 \%$, the 18 gram, 6 inch, 30\% weam test bottle with 1/2\% gradnations can be nsed. It is not neressary in such cases to use the $40 \%$ or $50 \%$ bottle. If reading's within $2 \%$ are desired, as is the case in researeh work or in cases for conrt, the $30 \%, 18$ gram, 9 inch cream test bottle grathated in .2\% divisions "an be nsed.

In most of the Wisconsin ereameries the $40 \%, 18$ gram, 6 inch ream test bottle will be found to be gradnated suffieiently high to test all samples of cream hronght to the factory. In creancries where the percent of fat in the cream rums above $40 \%$, either the $50 \%, 18$ gram, 7 inch cream test bottle or the $50 \%, 18$ gram, 9 inch cream test bottle wan be used. Owing to the claim by dairymen that a large amomnt of breakage results throngly the use of the 9 inch bottle, a new type of bottle is approved, namely, the $50 \%, 18$ gram, 7 inch cream test bottle adapted to use in centrifuges of wide dianeter.

Where creameries do not desire to go to the expense of installing a centrifuge that will hold 7 or 9 inch bottles, a $40 \%$, 18 gram, 6 inch hottle ean he used. If cream runs over $40 \%$, a 9 gram charge can be weighed into the bottle and 9 grams of water added before the acid is placed in the bottle. The reading obtained will have to be multiplied by two. When sensitive eream suales are nserl, the doubling of any error due to inacenrate weighings will be excerelingly slight. The dilution of eoncentrated cream with water "anses it to approximate more closely the eomposition of milk, and it is to be borne in mind that the Babcork test was originally designed for the determination of the butter fat of milk and not of eream. 
Owing to the opinion of the attorney gemeral that the law does

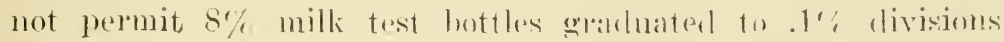
being sealed, this type is not inclumed in the sperifieations. Furthermore, it is highly desiralule from the stamdpoint of aleeuraey to have all milk bottles witl necks of alpproximately the same diameter. In reading the fat "ontent of milk, the realing is taken to the top of the meniscus. Shortening the diameter of the neek changes the shape of this menisens and produees an error in the reating which thongh small is apprexiable. As many of the $8 \%$ bottles in use have narrower necks than the $10 \%$ bottle; a constant error is thus introduced. if this type of bottle is used.

The use of Babeock glassware eomplying with these specifications will do away with many of the disputes hetween factoryman and patron now dne to the nee of inacenrate glassware. 


